\title{
Kisspeptin-GPR54 Signaling Is Essential for Preovulatory Gonadotropin-Releasing Hormone Neuron Activation and the Luteinizing Hormone Surge
}

\author{
Jenny Clarkson, ${ }^{1}$ Xavier d'Anglemont de Tassigny, ${ }^{2}$ Adriana Santos Moreno, ${ }^{1}$ William H. Colledge, ${ }^{2}$ and \\ Allan E. Herbison ${ }^{1}$ \\ ${ }^{1}$ Centre for Neuroendocrinology, Department of Physiology, University of Otago School of Medical Sciences, Dunedin 9054, New Zealand, and \\ ${ }^{2}$ Reproductive Physiology Group, Department of Physiology, Development, and Neuroscience, University of Cambridge, Cambridge CB2 3EG, United \\ Kingdom
}

\begin{abstract}
Kisspeptin and its receptor GPR54 have recently been identified as key signaling partners in the neural control of fertility in animal models and humans. The gonadotropin-releasing hormone $(\mathrm{GnRH})$ neurons represent the final output neurons of the neural network controlling fertility and are suspected to be the primary locus of kisspeptin-GPR54 signaling. Using mouse models, the present study addressed whether kisspeptin and GPR54 have a key role in the activation of GnRH neurons to generate the luteinizing hormone (LH) surge responsible for ovulation. Dual-label immunocytochemistry experiments showed that $40-60 \%$ of kisspeptin neurons in the rostral periventricular area of the third ventricle (RP3V) expressed estrogen receptor $\alpha$ and progesterone receptors. Using an ovariectomized, gonadal steroid-replacement regimen, which reliably generates an LH surge, 30\% of RP3V kisspeptin neurons were found to express c-FOS in surging mice compared with $0 \%$ in nonsurging controls. A strong correlation was found between the percentage of c-FOSpositive kisspeptin neurons and the percentage of c-FOS-positive GnRH neurons. To evaluate whether kisspeptin and/or GPR54 were essential for GnRH neuron activation and the LH surge, Gpr54- and Kiss1-null mice were examined. Whereas wild-type littermates all exhibited LH surges and c-FOS in $\sim 50 \%$ of their GnRH neurons, none of the mutant mice from either line showed an LH surge or any GnRH neurons with c-FOS. These observations provide the first evidence that kisspeptin-GPR54 signaling is essential for GnRH neuron activation that initiates ovulation. This broadens considerably the potential roles and therapeutic possibilities for kisspeptin and GPR54 in fertility regulation.
\end{abstract}

Key words: GPR54; kisspeptin; estrogen (estradiol); GnRH; gonadotropin; transgenic

\section{Introduction}

Two seminal clinical studies in 2003 identified kisspeptin and its receptor GPR54 to be essential for puberty onset and normal human fertility (de Roux et al., 2003; Seminara et al., 2003). Since that time, investigations in several different animal models have suggested that the key kisspeptin-GPR54 signaling event controlling reproduction occurs at the level of the gonadotropinreleasing hormone $(\mathrm{GnRH})$ neurons (Kauffman et al., 2007c; Smith and Clarke, 2007), the final output cells of the neuronal network initiating puberty and controlling fertility. Key insights into the role of kisspeptin-GPR54 signaling at the time of puberty have come from knock-out mouse models. Mice with mutations of either GPR54 or kisspeptin are reported to be overtly normal

Received April 23, 2008; revised June 29, 2008; accepted July 22, 2008.

This work was supported by the New Zealand Marsden Fund and Health Research Council, Takeda Cambridge, United Kingdom Biotechnology and Biological Sciences Research Council Grant BB/C0003861/1, the Ford Physiology Fund (W.H.C.), and CNP ${ }_{\mathrm{q}}$ Brazil (A.S.M.).

Correspondence should be addressed to Allan E. Herbison, Centre for Neuroendocrinology, Department of Physiology, University of Otago School of Medical Sciences, P.0. Box 913, Dunedin 9054, New Zealand. E-mail: allan.herbison@stonebow.otago.ac.nz.

DOI:10.1523/JNEUROSCI.1775-08.2008

Copyright $\odot 2008$ Society for Neuroscience $\quad 0270-6474 / 08 / 288691-07 \$ 15.00 / 0$ with the single exception that they fail to go through puberty (Funes et al., 2003; Seminara et al., 2003; d'Anglemont de Tassigny et al., 2007; Lapatto et al., 2007). These studies, alongside evidence that activation of GPR54 signaling can advance puberty onset in rodents and primates (Navarro et al., 2004; Shahab et al., 2005), have defined a key role for kisspeptin-GPR54 signaling in mammalian reproductive neurobiology.

Given the importance of the kisspeptin-GPR54-GnRH neuron axis in puberty, it has been logical to explore other potential roles of this signaling cascade in the control of reproduction. Recent data suggest involvement in the seasonal activation of $\mathrm{GnRH}$ neurons in hamsters (Revel et al., 2006; Greives et al., 2007) and sheep (Smith et al., 2007), as well as a role in activation of the GnRH neurons to generate the preovulatory luteinizing hormone (LH) surge. In terms of the latter, Kinoshita et al. (2005) and Adachi et al. (2007) have shown that injection of kisspeptin antisera into the vicinity of the GnRH neuron cell bodies prevents the LH surge in both proestrous and ovariectomized estrogentreated $(\mathrm{OVX}+\mathrm{E})$ rats. Furthermore, kisspeptin neurons located in the anteroventral periventricular nucleus (AVPV) of the rat express estrogen receptor $\alpha(\mathrm{ER} \alpha)$ (Smith et al., 2006; Adachi et al., 2007), known to be essential for estrogen positive feedback 
(Wintermantel et al., 2006). They also express the immediate early gene c-FOS, a molecular marker indicative of intense neural activation, at the time of the $\mathrm{OVX}+\mathrm{E} \pm$ progesterone-evoked $\mathrm{LH}$ surge. Although these data suggest involvement of kisspeptinGPR54 in the GnRH surge mechanism, Dungan et al. (2007) very recently reported that GPR54 was not critical for this mechanism, because one of the GPR54 mutant mouse lines was found to exhibit an LH surge.

To provide a thorough evaluation of the role of kisspeptinGPR54 signaling in the GnRH surge mechanism, we have undertaken a series of cellular and whole-animal investigations in mice. First, we set out to determine whether kisspeptin neurons in mice expressed the appropriate receptors required for gonadal steroid positive feedback, and whether they were activated at the time of the LH surge, as had been found previously in the rat. Second, using both Gpr54- and Kiss1-null mice, we examined whether either the receptor and/or ligand were essential for the preovulatory activation of the GnRH neurons and the LH surge.

\section{Materials and Methods}

Animals

Experiments were undertaken on adult (60-90 d of age) female C57BL/6J mice and 129S6/Sv/Ev Gpr54- (Seminara et al., 2003) and Kiss1- (d'Anglemont de Tassigny et al., 2007) null mice and their wildtype siblings. All mice were housed under a 12:12 h lighting schedule (lights on at 6:00 or 6:30 A.M.) with ad libitum access to food and water. For some experiments, vaginal smears were taken daily to provide mice on a specific day of the cycle. All experimental protocols were performed under the authority of the University of Otago Animal Welfare and Ethics Committee (Project 82/05) or a United Kingdom Home Office Project License and were approved by the Cambridge Animal Ethics Committee.

\section{Surge protocols}

OVX $+E$ protocol. Adult female C57BL/6J mice $(n=5-6 /$ group $)$ were treated as reported previously (Wintermantel et al., 2006). In brief, mice were anesthetized with halothane, bilaterally ovariectomized, and given subcutaneous SILASTIC implants containing $17-\beta$-estradiol (E2; 1 $\mu \mathrm{g} / 20 \mathrm{~g}$ of body weight) according to Bronson (1981). The SILASTIC capsules are made by dissolving crystalline $\mathrm{E} 2$ with ethanol and mixing it with SILASTIC medical adhesive, which is then injected into $1 \mathrm{~mm}$ (internal diameter $) \times 2.125 \mathrm{~mm}$ (external diameter) SILASTIC tubing (Dow Corning). Once dried, the tubing is cut to size depending on the weight of the mouse such that a $20 \mathrm{~g}$ mouse receives a $1 \mathrm{~cm}$ length of tubing ( $1 \mu \mathrm{g}$ of E2). Six days later, mice received an injection of estradiol benzoate (OVX $+\mathrm{E} ; 1 \mu \mathrm{g} / 20 \mathrm{~g}$ of body weight, s.c.) or vehicle (OVX+V; sesame oil) at 9:00 A.M. On the following day between 5:30 and 6:30 P.M., animals were anesthetized with pentobarbital ( $3 \mathrm{mg} / 100 \mu$ l, i.p.), a blood sample was taken from the right atrium or inferior vena cava, and the mice were transcardially perfused with $15 \mathrm{ml}$ of $4 \%$ paraformaldehyde in PBS.

$O V X+E+$ progesterone protocol. In initial experiments with wild-type $129 \mathrm{~S} 6 / \mathrm{Sv} /$ Ev mice, we found that only $\sim 50 \%$ of mice exhibited a robust $\mathrm{LH}$ surge using the OVX $+\mathrm{E}$ protocol. This was despite $100 \%$ of mice showing clear evidence of GnRH neuron activation through c-FOS (our unpublished observations). Hence, for the present study we used an $\mathrm{OVX}+\mathrm{E}+$ progesterone $(\mathrm{OVX}+\mathrm{E}+\mathrm{P})$ model that was found to generate an LH surge in $100 \%$ of $129 \mathrm{~S} 6 / \mathrm{Sv} / \mathrm{Ev}$ mice. In this protocol, mice were treated in exactly the same manner as for the $\mathrm{OVX}+\mathrm{E}$ mice with the exception that a single injection of progesterone $(500 \mu \mathrm{g} / 20 \mathrm{~g}$ of body weight) was given at 9:00 A.M. on the day of the surge, and animals were perfused between 5:45 and 6:15 P.M.

\section{Immunocytochemistry}

Free-floating, dual-label chromogen immunocytochemistry was undertaken as reported previously (Herbison et al., 1995; Wintermantel et al., 2006). Briefly, three sets of $30-\mu \mathrm{m}$-thick coronal brain sections, taken from the level of the medial septum through to the caudal hypothalamus, were cut on a freezing microtome from each brain. Sections were treated with $3 \%$ hydrogen peroxide for $10 \mathrm{~min}$ to quench endogenous peroxidase activity and then washed in Tris-buffered saline (TBS). For the first immunolabeling, sections were incubated for $48 \mathrm{~h}$ at $4^{\circ} \mathrm{C}$ in rabbit polyclonal primary antisera directed against either $\mathrm{ER} \alpha$, progesterone receptor (PR), or c-FOS in TBS containing $0.3 \%$ Triton X-100 and $0.25 \%$ BSA and $2 \%$ normal goat serum. Sections were then incubated in biotinylated anti-rabbit immunoglobulins (Vector Laboratories) at 1:400 for $90 \mathrm{~min}$ at room temperature. After subsequent washing in TBS, the sections were incubated in Vector Elite avidin-peroxidase (Vector Laboratories) at 1:100 for $90 \mathrm{~min}$ at room temperature. Immunoreactivity was revealed using glucose-oxidase, nickel-enhanced diaminobenzidine hydrochloride that resulted in a black precipitate within the nucleus of the labeled cell. For the second immunolabeling, sections were washed in 3\% hydrogen peroxide to quench any remaining peroxidase, washed in TBS, and then incubated in a polyclonal rabbit anti-GnRH or anti-kisspeptin antiserum containing $2 \%$ goat serum for $48 \mathrm{~h}$ at $4^{\circ} \mathrm{C}$. Sections were then incubated in peroxidase-labeled anti-rabbit immunoglobulins (1:400; Vector Laboratories) for $4 \mathrm{~h}$ at room temperature. Immunoreactivity was then revealed using glucose-oxidase, diaminobenzidine hydrochloride without nickel to generate a brown precipitate within the cytoplasm.

Polyclonal rabbit antisera directed against ER $\alpha$ (1:10,000; Millipore), PR (1:2000; Dako), c-FOS (1:8000; SC52; Santa Cruz Biotechnology), kisspeptin-10 (1:5000; gift from A. Caraty, Institut National de la Recherche Agronomique, Paris, France), and GnRH (1:20,000; LR5; gift from R. Benoit, affiliation unknown, Montreal, Canada) have all been characterized previously (Haywood et al., 1999; Li et al., 1999; Clarkson and Herbison, 2006b; Wintermantel et al., 2006). In the present set of experiments, removal of antisera resulted in an absence of appropriate immunoreactivity.

\section{Immunocytochemistry analysis}

Sections were examined using an Olympus BX51 microscope using bright-field microscopy. Analysis of the double-labeled tissue was undertaken by counting the number of single-labeled (brown cytoplasm only) and dual-labeled (brown cytoplasm and black nucleus) GnRH or kisspeptin neurons. GnRH neurons were counted in two sections containing the medial septum (MS) and two sections containing the rostral preoptic area (rPOA) corresponding to plates 22-24 and 25-27, respectively, of the Franklin and Paxinos (1997) brain atlas. Kisspeptin neurons exist in the rostral hypothalamus as a periventricular continuum within the AVPV and preoptic periventricular nucleus (PVpo) (Clarkson and Herbison, 2006b) referred to here as the rostral periventricular area of the third ventricle (RP3V) (Herbison, 2008). Because no detailed information exists of these brain areas in existing mouse brain atlases, Herbison has recently published an anatomical description of the AVPV and PVpo in the C57BL/6J mouse brain [Herbison (2008), his Fig. 4]. We have used this map to analyze kisspeptin neurons at three levels of the RP3V: the AVPV [Herbison (2008), his Fig. 4, plate C; approximately equivalent to Franklin and Paxinos (1997), their plate 29], rostral PVpo (rPVpo) [Herbison (2008), his Fig. 4, plate D; approximately equivalent to Franklin and Paxinos (1997), their plate 30], and caudal PVpo (cPVpo) [Herbison (2008), his Fig. 4, plates E, F; approximately equivalent to Franklin and Paxinos (1997), their plate 31]. In each mouse, two sections at each of these levels were matched across the brains and analyzed. All counts are given as mean + SEM per brain section. Statistical analysis was undertaken with nonparametric ANOVA (Kruskal-Wallis) and post hoc Dunn's multiple-comparisons test.

Experiment 1: ER $\alpha$ and PR expression in RP3V kisspeptin neurons Six diestrous and four proestrous wild-type C57BL/6J mice were used for dual-label kisspeptin-ER $\alpha$ and kisspeptin-PR experiments, respectively. Because expression of the PR is upregulated by estrogen in the preoptic area (Simerly et al., 1996; Shughrue et al., 1997), PR experiments were undertaken at proestrus.

\section{Experiment 2: c-FOS expression in RP3V kisspeptin neurons}

Twelve adult female wild-type C57BL/6J mice underwent the OVX $+\mathrm{E}$ protocol, with half given estradiol benzoate injection and half given vehicle. Blood was collected for LH radioimmunoassay, and c-FOS- 
positive cells were detected with immunocytochemistry in all three sets of sections. One set of c-FOS-immunoreacted sections then underwent sequential immunolabeling with the GnRH antisera, and the other two sets of c-FOS sections were immunostained for kisspeptin. Plasma LH was assayed by radioimmunoassay as reported previously (Herbison et al., 2008). The sensitivity was $0.4 \mathrm{ng} / \mathrm{ml}$ with an intra-assay coefficient of variation of $12.1 \%$. Statistical analysis of percentage of kisspeptin with c-FOS between groups was undertaken with nonparametric ANOVA (Kruskal-Wallis) and post hoc Dunn's multiple-comparisons test. Analysis of LH levels was undertaken by nonparametric Mann-Whitney test.

\section{Experiment 3: positive feedback in Gpr54 and Kiss1}

knock-out mice

Preliminary experiments with adult female 129S6/Sv/Ev mice showed that the OVX $+\mathrm{E}+\mathrm{P}$ surge protocol resulted in peak $\mathrm{LH}$ levels between 5:30 and 6:30 P.M. Adult female Gpr54-null and Kiss1-null mice and their wild-type littermates ( $n=5$ each group) were housed together in groups of three (one of each genotype) and underwent the OVX $+\mathrm{E}+\mathrm{P}$ surge protocol with blood collected for LH assay and one set of brain sections used for dual-labeling c-FOS and GnRH immunocytochemistry and another set used for dual-labeling c-FOS and kisspeptin immunocytochemistry. LH was assayed using an ELISA (Endocrine Technologies) with a sensitivity of $0.33 \mathrm{ng} / \mathrm{ml}$ and a $7 \%$ intra-assay coefficient of variation. Genotyping was undertaken by PCR as reported previously (Seminara et al., 2003; d'Anglemont de Tassigny et al., 2007). Statistical analysis of immunocytochemistry and LH levels was undertaken with nonparametric ANOVA (Kruskal-Wallis) and post hoc Dunn's multiplecomparisons test.

\section{Results}

\section{Kisspeptin neurons in the RP3V express ER $\alpha$ and PR}

As reported previously (Clarkson and Herbison, 2006a), kisspeptin-immunoreactive cell bodies were identified as a periventricular continuum within the AVPV and PVpo with cell numbers per section increasing with more caudal location in the RP3V (Fig. 1C,D). Dual-labeling immunocytochemistry for kisspeptin and $\mathrm{ER} \alpha$ in diestrous mice demonstrated the presence of many cells with brown cytoplasmic staining for kisspeptin and black nuclear staining for ER $\alpha$ (Fig. 1A) throughout the RP3V. The percentages of kisspeptin neurons expressing ER $\alpha$ within the AVPV, rPVpo, and cPVpo divisions of the RP3V were $64 \pm 8 \%$, $45 \pm 8 \%$, and $36 \pm 7 \%$, respectively (Fig. $1 E)(n=6)$. Duallabeling immunocytochemistry for kisspeptin and $\mathrm{PR}$ in proestrous mice $(n=4)$ similarly resulted in many dual-labeled cells (Fig. $1 B$ ) being detected throughout the RP3V. The percentages of kisspeptin neurons expressing PR within the AVPV, rPVpo, and cPVpo were $67 \pm 4 \%, 65 \pm 5 \%$, and $64 \pm 5 \%$, respectively (Fig. $1 F)$.

These data indicate that RP3V kisspeptin neurons are equipped with the appropriate gonadal steroid hormone receptors required for positive feedback to generate the $\mathrm{LH}$ surge.

\section{Kisspeptin neurons in the RP3V express c-FOS at the time of the GnRH/LH surge}

In OVX $+\mathrm{E}$ mice, dual-labeled $\mathrm{GnRH}+\mathrm{c}-\mathrm{FOS}$ cells (Fig. 2A) were found almost exclusively within the rPOA, with very few double-labeled cells detected in the MS (data not shown). Whereas $54 \pm 7 \%$ of rPOA GnRH neurons were positive for c-FOS in OVX +E mice, no GnRH neurons in the rPOA or MS expressed c-FOS in the OVX $+\mathrm{V}$ group $(p<0.001)$ (Fig. $2 D$ ) $(n=5-6$ each group). All mice in the OVX + E group exhibited an LH surge (mean, $5.3 \pm 1.7 \mathrm{ng} / \mathrm{ml}$ ) compared with significantly lower LH levels in the OVX $+\mathrm{V}$ group $(1.4 \pm 0.3 \mathrm{ng} / \mathrm{ml} ; p<0.05)$ (Fig. $2 F$ ). The numbers of GnRH neurons detected in the rPOA and $\mathrm{MS}$ of $\mathrm{OVX}+\mathrm{E}$ and $\mathrm{OVX}+\mathrm{V}$ mice were not different (Fig. $2 C)$.
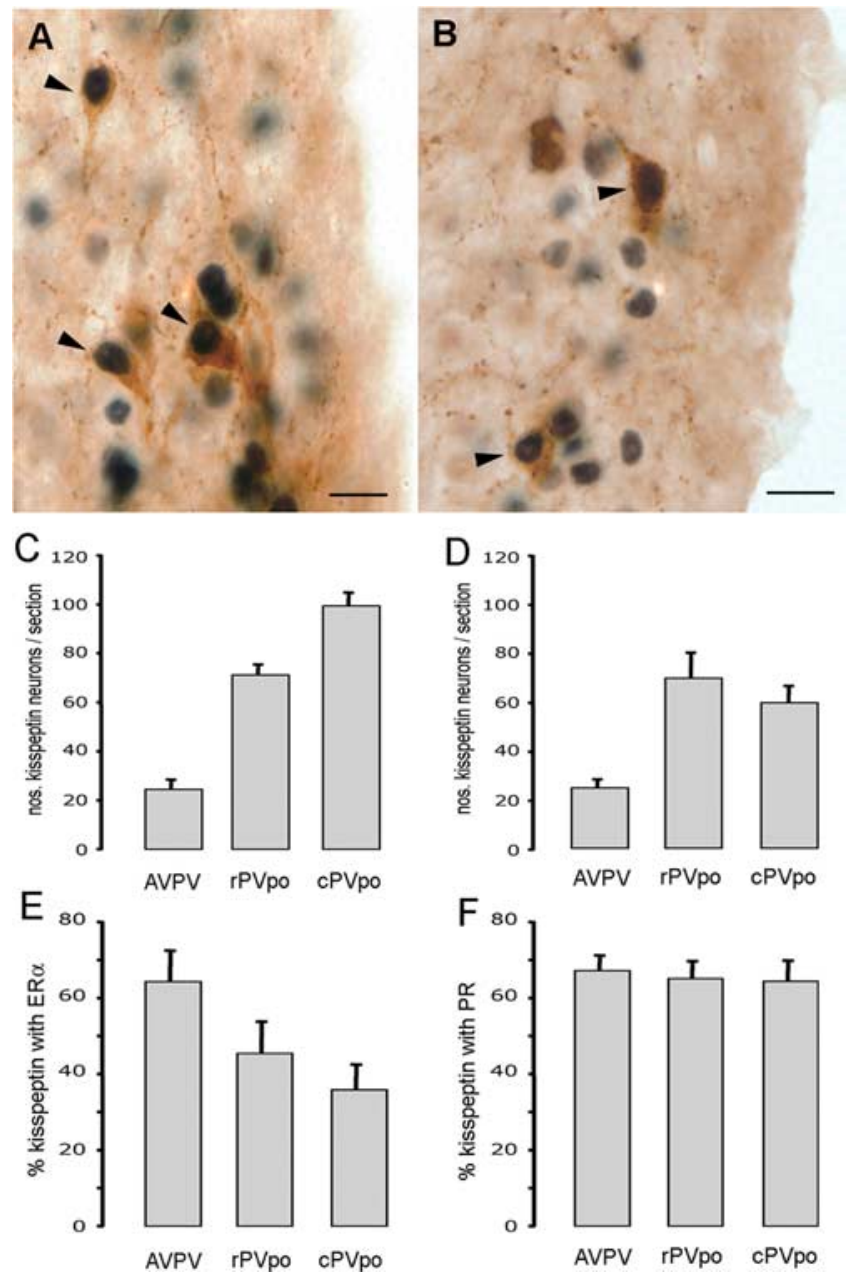

Figure 1. RP3V kisspeptin neurons express ER $\alpha$ and PR. A, Dual-label immunocytochemistry showing AVPV kisspeptin neurons (brown) with ER $\alpha$-immunoreactive nuclei (black). Arrowheads indicate dual-labeled cells. $\boldsymbol{B}$, Dual-label immunocytochemistry showing PVpo kisspeptin neurons (brown) with PR-immunoreactive nuclei (black). C, Bar graph showing the mean + SEM number of kisspeptin-immunoreactive neurons counted per section at the three levels of the RP3V (AVPV, rPVpo, and (PVpo) in the ER $\alpha$ dual-labeling study. D, Bar graph showing the number of kisspeptin neurons counted per section in the AVPV, rPVpo, and CPVpo in the PR dual-labeling study. $\boldsymbol{E}, \boldsymbol{F}$, Percentage of kisspeptin neurons expressing $E R \alpha(\boldsymbol{E})$ and PR (F) throughout the RP3V. Scale bars, $10 \mu \mathrm{m}$.

The numbers and distribution of kisspeptin neurons within the RP3V were the same in OVX +E and OVX + V mice (Fig. $2 \mathrm{E}$ ). Kisspeptin neurons were found to express c-FOS (Fig. $2 B$ ) in each of the OVX $+\mathrm{E}$ mice with mean percentage values of $33 \pm$ $4 \%, 24 \pm 4 \%$, and $35 \pm 3 \%$ of kisspeptin neurons with c-FOS in the AVPV, rPVpo, and cPVpo, respectively $(n=6)($ Fig. $2 H)$. In contrast, no RP3V kisspeptin neurons expressed c-FOS in any of the six OVX $+\mathrm{V}$ mice $(p<0.001)$ (Fig. $2 H)$.

To examine the relationship between the percentage of kisspeptin neurons expressing c-FOS and the percentage of GnRH neurons expressing c-FOS, we plotted the respective percentages for each animal in the $\mathrm{OVX}+\mathrm{E}$ and $\mathrm{OVX}+\mathrm{V}$ groups. A good correlation was found within the AVPV and the PVpo combined $\left(R^{2}\right.$ values of 0.832 and 0.866 for the AVPV and PVpo, respectively) with mice exhibiting highest GnRH/c-FOS coexpression also exhibiting the highest kisspeptin/c-FOS coexpression (Fig. 2G).

These data show that RP3V kisspeptin neurons are activated at the time of estrogen positive feedback that initiates the $\mathrm{GnRH} / \mathrm{LH}$ surge. 


\section{Both Gpr54 and Kiss1 are essential for GnRH neuron activation and the LH surge}

To evaluate the necessity of both GPR54 and kisspeptin for the GnRH/LH surge mechanism, the ability of exogenous gonadal steroids to activate $\mathrm{GnRH}$ neurons and generate the LH surge was evaluated in Gpr54-null (Seminara et al., 2003) and Kiss1-null mice (d'Anglemont de Tassigny et al., 2007). Five mice of each genotype underwent the $\mathrm{OVX}+\mathrm{E}+\mathrm{P}$ protocol with mice being killed between 5:45 and 6:15 P.M., the time of peak LH secretion in the $129 S 6 / \mathrm{Sv} / \mathrm{Ev}$ strain. The numbers of $\mathrm{GnRH}$ neurons identified in the $\mathrm{rPOA}$ were the same in all three genotypes (Fig. $3 D)$. As found in the OVX +E experiments in $\mathrm{C} 57 \mathrm{BL} / 6 \mathrm{~J}$ mice, $55 \pm 7 \%$ of $\mathrm{rPOA}$ GnRH neurons expressed c-FOS in wildtype $129 \mathrm{~S} 6 / \mathrm{Sv} / \mathrm{Ev}$ mice (Fig. 3A,F). In contrast, no GnRH neurons expressed c-FOS in either Gpr54-null or Kiss1-null mice $(p<0.001)$ (Fig. $3 B, C, F)$. All five wild-type siblings exhibited an $\mathrm{LH}$ surge (mean LH of $3.3 \pm 0.8 \mathrm{ng} / \mathrm{ml}$; individual values of $1.48,2.26,2.63,5.05$, and 5.27 $\mathrm{ng} / \mathrm{ml}$ ), whereas none of the five Gpr54null or five Kiss1-mutant mice exhibited LH surges $(p<0.01$; individual values for all 10 mice either at or below $0.33 \mathrm{ng} / \mathrm{ml}$, the sensitivity of the LH ELISA) (Fig. $3 E$ ).

To evaluate whether kisspeptin neurons in Gpr54-null mice were still activated by E2, even though they could not communicate with GnRH neurons because of the absence of GPR54, we examined c-FOS expression in kisspeptin neurons of wild-type and Gpr54-null mice. The number of kisspeptinimmunoreactive neurons identified in the RP3V of Gpr54-null mice was approximately half or less that of wild-type littermates (Fig. 3G). The number of kisspeptin neurons in the AVPV of Gpr54-null mice just failed to reach statistical significance $(p=0.06)$ compared with controls, but those in the rostral $(p<0.05)$ and caudal $(p<0.01)$ PVpo were significantly reduced (Fig. 3G). However, the percentage of kisspeptin neurons expressing c-FOS was similar (30-40\%) between Gpr54-null and wild-type mice across the RP3V (Fig. $3 H$ ).

\section{Discussion}

We report here that kisspeptin and GPR54 are both essential for the preovulatory GnRH/LH surge in the mouse. The RP3V kisspeptin neurons in the mouse express $\mathrm{ER} \alpha$ and PR, and approximately one-third express c-FOS at the time of the steroidinduced GnRH/LH surge. Most importantly, we found a complete absence of both GnRH neuron activation and the LH surge in OVX +E + P Gpr54-null or Kiss1-mutant mice. Together, these data demonstrate that a gonadal steroid-kisspeptin-GPR54-

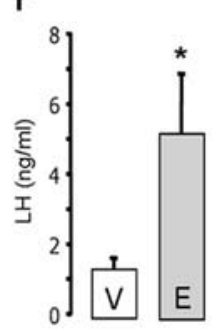

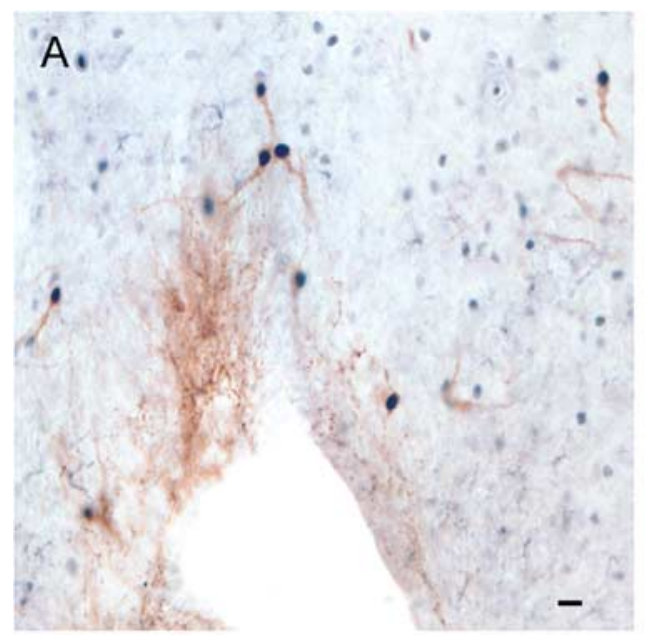
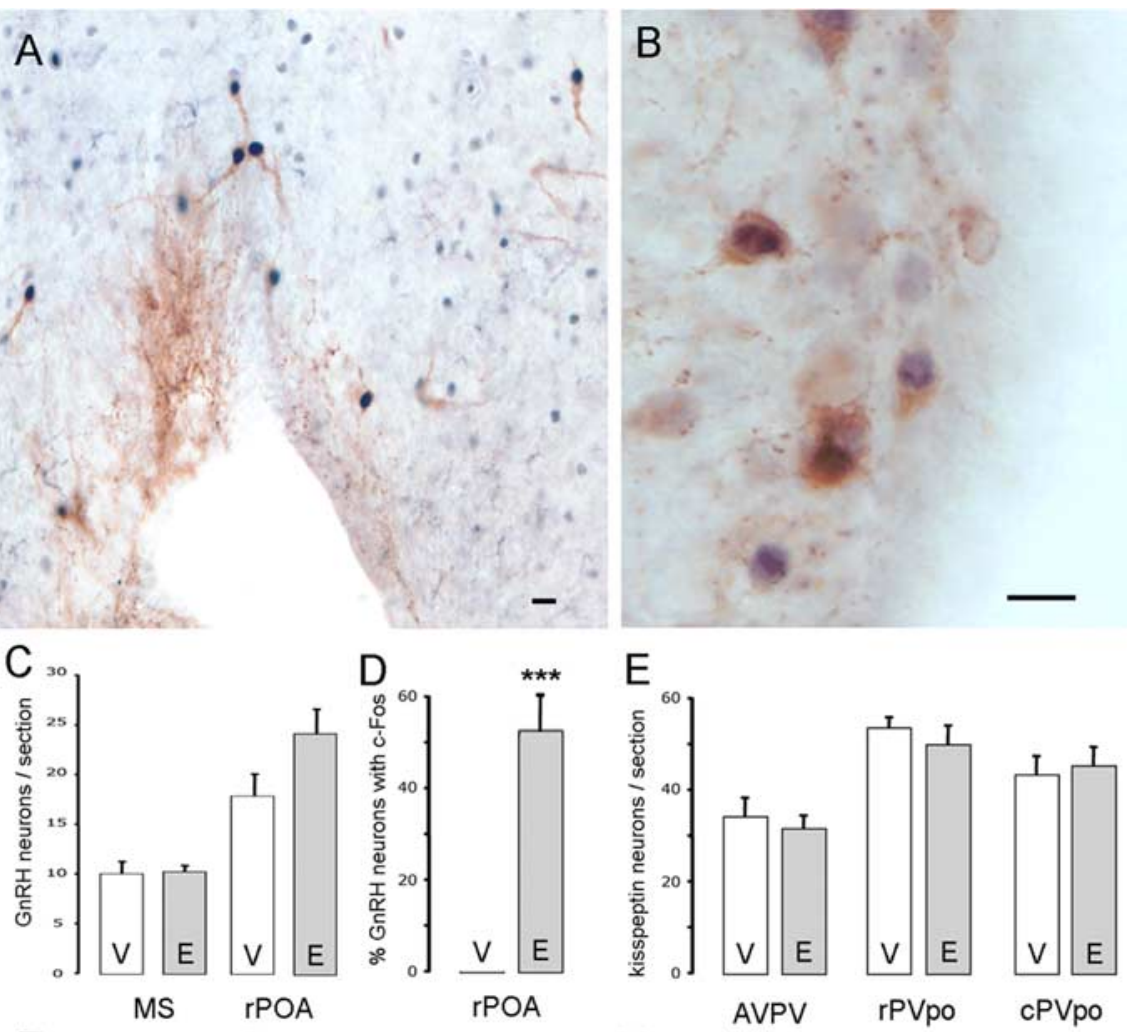

G

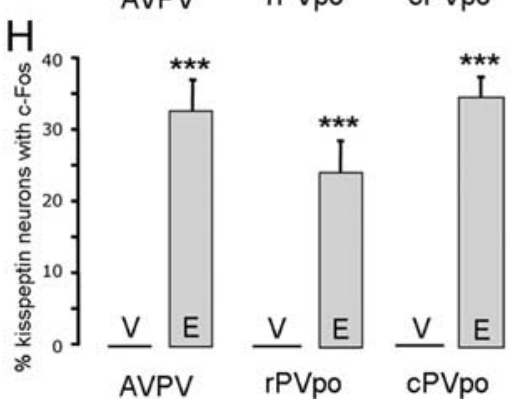

Figure 2. RP3V kisspeptin neurons express c-FOS at the time of the GnRH/LH surge. $A$, Dual-label immunocytochemistry showing GnRH neurons (brown) with c-FOS-immunoreactive nuclei (black). $\boldsymbol{B}$, Dual-label immunocytochemistry showing AVPV kisspeptin neurons (brown) with c-FOS immunoreactive nuclei (black). C, Bar graph showing the mean + SEM number of GnRH neurons counted per section in the MS and $\mathrm{PPOA}$ of $\mathrm{OVX}+\mathrm{E}-(\mathrm{E})$ and $\mathrm{OVX}+\mathrm{V}-(\mathrm{V})$ treated wild-type mice. D, Percentage of $\mathrm{PPOA}$ $\mathrm{GnRH}$ neurons expressing c-FOS in OVX+E- and OVX + V-treated wild-type mice. $E$, Bar graph showing the number of kisspeptin neurons counted per section in the AVPV, rPVpo, and $c P V p o$ in $O V X+E$ - and $O V X+V$-treated wild-type mice. $F$, Bar graph showing the LH levels in OVX+E- and OVX+V-treated wild-type mice. G, Graph showing the positive correlation between percentage of GnRH neurons with c-FOS and percentage of RP3V kisspeptin neurons with c-FOS in the AVPV and the PVpo combined. $\boldsymbol{H}$, Percentage of kisspeptin neurons at the three levels of the RP3V expressing c-FOS in OVX $+\mathrm{E}$ - and OVX+V-treated wild-type mice. ${ }^{*} p<0.05,{ }^{* *} p<0.001, V$ versus E. Scale bars, $10 \mu \mathrm{m}$.

GnRH neuron pathway is essential for GnRH neuron activation leading to ovulation.

Recent investigations in the mouse have shown that $\mathrm{ER} \alpha$, acting as a classical transcription factor, is essential for estrogen positive feedback to generate the $\mathrm{GnRH} / \mathrm{LH}$ surge (Wintermantel et al., 2006; Glidewell-Kenney et al., 2007). Evidence in both the rat and mouse demonstrate that the key ER $\alpha$-expressing neurons innervating $\mathrm{GnRH}$ neurons reside within the RP3V (Herbison, 1998, 2008; Petersen et al., 2003). Thus, a primary requirement for a neuronal phenotype to be involved in the estrogen positive feedback mechanism is that it is located in the RP3V and expresses $\operatorname{ER} \alpha$. We show here that this is indeed the case for mouse RP3V kisspeptin neurons, and that this is similar to the rat. Smith et al. (2006) found that $62 \%$ of AVPV Kiss1 mRNA cells ex- 


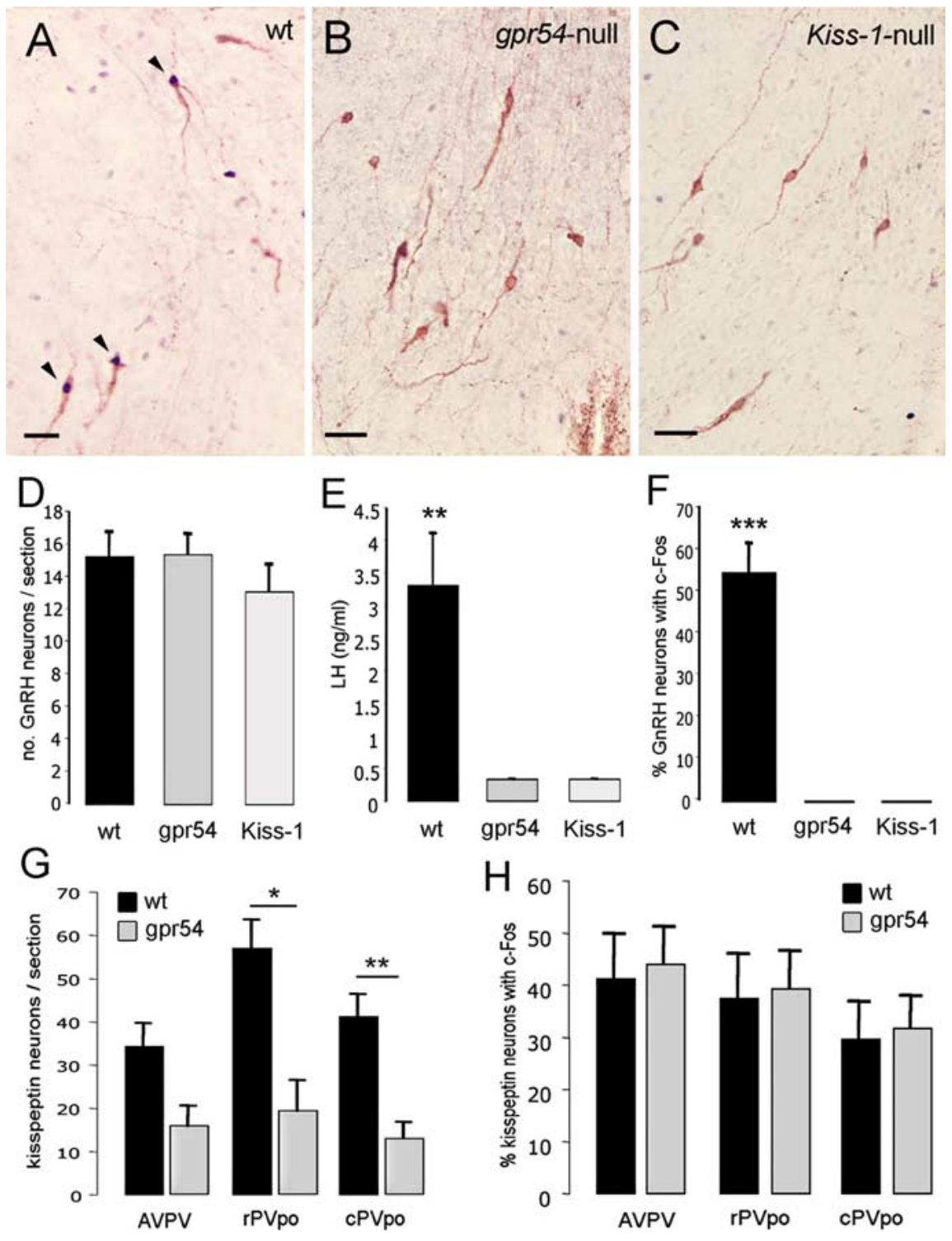

Figure 3. Both the LH surge and GnRH neuron activation are absent in Gpr54- and Kiss1-null mice. $A$, Dual-label immunocytochemistry showing three GnRH neurons (brown) expressing c-FOS (black nuclei) in wild-type siblings. $\boldsymbol{B}$, Dual-label immunocytochemistry showing absence of c-FOS staining in GnRH neurons of Gpr54-null mice. C, Dual-label immunocytochemistry showing absence of c-FOS staining in GnRH neurons of Kiss 1-null mice. D, Bar graph showing the mean + SEM number of GnRH neurons counted per section in rPOA of wild-type siblings (wt) and Gpr54- (gpr54) and Kiss 1- (Kiss-1) null mice. E, Mean + SEM LH levels in OVX $+E+P$ mice of the three genotypes. $F$, Percentage of GnRH neurons expressing c-FOS in OVX $+E+P$ mice of the three genotypes. G, Bar graph showing the mean + SEM number of kisspeptin neurons counted per section in the AVPV, rPVpo, and cPVpo of wild-type and Gpr54-null mice. $\boldsymbol{H}$, Percentage of kisspeptin neurons expressing c-FOS in the AVPV, rPVpo, and cPVpo of OVX+E + P wild-type and Gpr54-null mice. ${ }^{*} p<0.05,{ }^{* *} p<0.01,{ }^{* * *} p<0.001$, wt versus gpr54 or Kiss-1 or as indicated. Scale bars, $20 \mu \mathrm{m}$.

pressed ER $\alpha$-mRNA in the rat. We report a very similar percentage (64\%) in the AVPV of the mouse but also highlight the importance of defining the precise location of kisspeptin neurons within the RP3V; kisspeptin cells positioned more caudally within the periventricular continuum were found to have a lower probability of expressing ER $\alpha$.

Our studies also provide evidence for the expression of the PR by $\sim 60 \%$ of RP3V kisspeptin neurons. Investigations in the ewe have shown that the great majority of kisspeptin neurons located in the arcuate nucleus express PR (Smith et al., 2007). There is increasing evidence that both ligand-dependent and -independent activation of PR within the vicinity of the AVPV may be critical for the LH surge mechanism in rats and mice (Levine, 1997; Chappell and Levine, 2000; Micevych et al., 2008). Hence, the identification of the PR, as well as $\mathrm{ER} \alpha$, in RP3V kisspeptin neurons puts them in a prime position to mediate steroid positive feedback to $\mathrm{GnRH}$ neurons.

Electrophysiological studies show that kisspeptin is an extremely potent activator of $\mathrm{GnRH}$ neurons, with exposure to kisspeptin at proestrus resulting in prolonged intense firing by GnRH neurons (Han et al., 2005). This intense activation of GnRH neurons occurs through the joint modulation of potassium and nonspecific cation/transient receptor potential channels (Liu et al., 2008; Zhang et al., 2008). As reported for the rat (Smith et al., 2006; Adachi et al., 2007), a subpopulation of kisspeptin neurons, located throughout the RP3V continuum, express c-FOS at the time of the GnRH/LH surge in mice. This suggests that RP3V kisspeptin neurons have been activated immediately before, or at the time of, the GnRH/LH surge. In OVX mice treated with an estradiol capsule to bring about negative feedback, but not subsequently administered estradiol benzoate to evoke positive feedback, we found no c-FOS in RP3V kisspeptin neurons. Thus, the activation of $\mathrm{RP} 3 \mathrm{~V}$ kisspeptin neurons appears to be unique to the estrogen positive feedback environment.

Many different neuronal phenotypes located in the AVPV, and elsewhere, have been implicated in the generation of the GnRH/LH surge (Herbison, 1998; Petersen et al., 2003). At present, the RP3V kisspeptin neurons are the only ones that meet all of the criteria necessary to be considered a key neural component of the positive feedback pathway: (1) kisspeptin neurons are located in the RP3V, (2) RP3V kisspeptin neurons are sexually dimorphic favoring females (Clarkson and Herbison, 2006b; Kauffman et al., 2007a), (3) RP3V kisspeptin express ER $\alpha$ and PR, (4) RP3V kisspeptin neurons project to GnRH neurons [although not proven directly, the strong correlation between the developmental appearance and sex differences of RP3V kisspeptin cell bodies and kisspeptin fibers around GnRH neurons is compelling (Clarkson and Herbison, 2006b) ], (5) RP3V kisspeptin neurons are activated by estrogen positive feedback, and (6) GnRH neurons express GPR54 and are activated by kisspeptin (Irwig et al., 2004; Han et al., 2005). Together, these findings suggest that RP3V kisspeptin neurons play a key role in transmitting the steroid positive feedback signal to GnRH neurons. However, the potential for kisspeptin-GPR54 to be a key component took a substantial step backwards recently when Dungan et al. (2007) reported that female mice from a new Gpr54 mutant mouse line could mount an 
LH surge. In direct contradiction to that study, we show here that female mice from a different Gpr54-null line (Seminara et al., 2003) are unable to generate an LH surge or show evidence of GnRH neuron activation. Furthermore, we also show that female Kiss1-null mice are unable to exhibit GnRH neuron activation or an LH surge. This clearly demonstrates that both kisspeptin and GPR54 are essential for the GnRH surge mechanism. Whether kisspeptin-GPR54 signaling is sufficient on its own to generate the GnRH surge remains to be established, but the weight of data would suggest that other likely parallel signaling pathways are also involved in modulating the occurrence of the LH surge (Herbison, 2006).

There are two major differences between the Dungan study and our own. The first is that the Dungan Gpr54 mutant mouse was generated by retroviral insertion into intron 2 (H. Dungan, personal communication) with no loss of Gpr54 coding sequence. There are cases in which retroviral insertion does not always produce a null mutation but can generate a hypomorphic allele with residual gene function (Couldrey et al., 1999; Roshon and Ruley, 2005). The extent to which this may occur in the Dungan Gpr54 transgenic line has not been reported. Although these mice clearly exhibit hypogonadotropic hypogonadism, residual GPR54 expression may explain the persistence of the LH surge in approximately half of the OVX $+\mathrm{E}$ mice from this line. In contrast, the Gpr54-null line used in our studies has a complete knock-out of GPR54 (Seminara et al., 2003).

The second major difference between these two studies is that of the gonadal steroid regimens used to evoke the GnRH surge. The Dungan experiments used an OVX-constant E paradigm that generates daily LH surges (Christian et al., 2005). This unphysiological model results in $\mathrm{GnRH}$ neurons being activated every day, rather than every fourth or fifth day as in the normal estrous cycle. This likely explains the abnormal high levels of c-FOS expression by GnRH neurons in the morning, at a time of negative feedback in these mice, and the weak LH surges encountered in the Christian model (Dungan et al., 2007). In our studies, we have used an OVX $+\mathrm{E}+\mathrm{P}$ regimen that creates a single robust LH surge in $100 \%$ of wild-type mice. In preliminary experiments, we found that the OVX $+\mathrm{E}$ capsule $+\mathrm{E}$ injection regimen, which we use in C57BL/6J mice, was not 100\% reliable in generating an $\mathrm{LH}$ surge in $129 \mathrm{~S} 6 / \mathrm{Sv} / \mathrm{Ev}$ mice. Hence, we moved to an OVX $+\mathrm{E}$ capsule $+\mathrm{E}$ injection + progesterone injection regimen that results in better time locking of the onset of the surge (Herbison et al., 2008). With this model, we could demonstrate LH surges in $100 \%$ of wild-type $129 \mathrm{~S} 6 / \mathrm{Sv} / \mathrm{Ev}$ mice, and this provided the appropriate model to examine the surge mechanism in Gpr54- and Kiss1-null mice. Indeed, despite what might be considered a stronger gonadal steroid stimulus than estrogen alone, there was a complete failure of $\mathrm{GnRH}$ neuron activation and the $\mathrm{LH}$ surge in both Gpr54- and Kiss1-null mice.

Interestingly, we note here that the absolute number of kisspeptin-immunoreactive neurons found in the RP3V of Gpr54-null mice is about half that of wild-type animals. A previous study suggested that GPR54 was involved in the sexual differentiation of the mouse brain (Kauffman et al., 2007b). Whether the reduced number of kisspeptin-immunoreactive cells encountered here is caused by altered sexual differentiation of the brain or the chronic low levels of E2 in these mice (Seminara et al., 2003) is not known. The same proportions of RP3V kisspeptin cells do, nevertheless, respond to E2 positive feedback by expressing c-FOS in Gpr54-null mice. Thus, the deficit in positive feedback signaling in Gpr54-null mice is likely to result from a reduced kisspeptin drive as well as the complete absence of GPR54.

In summary, we demonstrate that kisspeptin and GPR54 are essential for the GnRH surge mechanism and ovulation. As indicated previously (Messager et al., 2005), it appears that there is no ligand or receptor redundancy in kisspeptin-GPR54 signaling with respect to GnRH neurons. Our studies show that RP3V kisspeptin neurons in the mouse express the appropriate gonadal steroid receptors for positive feedback and are activated at the appropriate time to initiate $\mathrm{GnRH}$ neuron firing resulting in the LH surge. Critically, we find that both GPR54 and kisspeptin are essential for the surge mechanism to occur. This extends the key physiological roles of kisspeptin-GPR54 signaling beyond that of puberty initiation into the generation of reproductive cycles in adult mammals. That kisspeptin and GPR54 are essential for each ovulation suggests further possibilities for this signaling system in the beneficial manipulation of human fertility.

\section{References}

Adachi S, Yamada S, Takatsu Y, Matsui H, Kinoshita M, Takase K, Sugiura H, Ohtaki T, Matsumoto H, Uenoyama Y, Tsukamura H, Inoue K, Maeda K (2007) Involvement of anteroventral periventricular metastin/kisspeptin neurons in estrogen positive feedback action on luteinizing hormone release in female rats. J Reprod Dev 53:367-378.

Bronson FH (1981) The regulation of luteinizing hormone secretion by estrogen: relationships among negative feedback, surge potential, and male stimulation in juvenile, peripubertal, and adult female mice. Endocrinology 108:506-516.

Chappell PE, Levine JE (2000) Stimulation of gonadotropin-releasing hormone surges by estrogen. I. Role of hypothalamic progesterone receptors. Endocrinology 141:1477-1485.

Christian CA, Mobley JL, Moenter SM (2005) Diurnal and estradioldependent changes in gonadotropin-releasing hormone neuron firing activity. Proc Natl Acad Sci U S A 102:15682-15687.

Clarkson J, Herbison AE (2006a) Development of GABA and glutamate signaling at the GnRH neuron in relation to puberty. Mol Cell Endocrinol 254-255:32-38.

Clarkson J, Herbison AE (2006b) Postnatal development of kisspeptin neurons in mouse hypothalamus; sexual dimorphism and projections to gonadotropin-releasing hormone neurons. Endocrinology 147:5817-5825.

Couldrey C, Carlton MB, Nolan PM, Colledge WH, Evans MJ (1999) A retroviral gene trap insertion into the histone 3.3A gene causes partial neonatal lethality, stunted growth, neuromuscular deficits and male subfertility in transgenic mice. Hum Mol Genet 8:2489-2495.

d'Anglemont de Tassigny X, Fagg LA, Dixon JP, Day K, Leitch HG, Hendrick AG, Zahn D, Franceschini I, Caraty A, Carlton MB, Aparicio SA, Colledge WH (2007) Hypogonadotropic hypogonadism in mice lacking a functional Kiss1 gene. Proc Natl Acad Sci U S A 104:10714-10719.

de Roux N, Genin E, Carel JC, Matsuda F, Chaussain JL, Milgrom E (2003) Hypogonadotropic hypogonadism due to loss of function of the KiSS1derived peptide receptor GPR54. Proc Natl Acad Sci USA 100:10972-10976.

Dungan HM, Gottsch ML, Zeng H, Gragerov A, Bergmann JE, Vassilatis DK, Clifton DK, Steiner RA (2007) The role of kisspeptin-GPR54 signaling in the tonic regulation and surge release of gonadotropin-releasing hormone/luteinizing hormone. J Neurosci 27:12088-12095.

Franklin KBJ, Paxinos G (1997) The mouse brain in stereotaxic coordinates. San Diego: Academic.

Funes S, Hedrick JA, Vassileva G, Markowitz L, Abbondanzo S, Golovko A, Yang S, Monsma FJ, Gustafson EL (2003) The KiSS-1 receptor GPR54 is essential for the development of the murine reproductive system. Biochem Biophys Res Commun 312:1357-1363.

Glidewell-Kenney C, Hurley LA, Pfaff L, Weiss J, Levine JE, Jameson JL (2007) Nonclassical estrogen receptor alpha signaling mediates negative feedback in the female mouse reproductive axis. Proc Natl Acad Sci U S A 104:8173-8177.

Greives TJ, Mason AO, Scotti MA, Levine J, Ketterson ED, Kriegsfeld LJ, Demas GE (2007) Environmental control of kisspeptin: implications for seasonal reproduction. Endocrinology 148:1158-1166. 
Han SK, Gottsch ML, Lee KJ, Popa SM, Smith JT, Jakawich SK, Clifton DK, Steiner RA, Herbison AE (2005) Activation of gonadotropin-releasing hormone $(\mathrm{GnRH})$ neurons by kisspeptin as a neuroendocrine switch for the onset of puberty. J Neurosci 25:11349-11356.

Haywood SA, Simonian SX, van der Beek EM, Bicknell RJ, Herbison AE (1999) Fluctuating estrogen and progesterone receptor expression in brainstem norepinephrine neurons through the rat estrous cycle. Endocrinology 140:3255-3263.

Herbison AE (1998) Multimodal influence of estrogen upon gonadotropinreleasing hormone neurons. Endocr Rev 19:302-330.

Herbison AE (2006) Physiology of the GnRH neuronal network. In: Knobil and Neill's physiology of reproduction, Ed 3 (Neill JD, ed), pp 1415-1482. San Diego: Academic.

Herbison AE (2008) Estrogen positive feedback to gonadotropin-releasing hormone $(\mathrm{GnRH})$ neurons in the rodent: the case for the rostral periventricular area of the third ventricle (RP3V). Brain Res Rev 57:277-287.

Herbison AE, King IS, Tan KC, Dye S (1995) Increased fos expression in preoptic calcitonin gene-related peptide (CGRP) neurones following mating but not the luteinizing hormone surge in female rats. J Neuroendocrinol 7:377-385.

Herbison AE, Porteous R, Pape JR, Mora JM, Hurst PR (2008) Gonadotropin-releasing hormone neuron requirements for puberty, ovulation, and fertility. Endocrinology 149:597-604.

Irwig MS, Fraley GS, Smith JT, Acohido BV, Popa SM, Cunningham MJ, Gottsch ML, Clifton DK, Steiner RA (2004) Kisspeptin activation of gonadotropin releasing hormone neurons and regulation of KiSS-1 mRNA in the male rat. Neuroendocrinology 80:264-272.

Kauffman AS, Gottsch ML, Roa J, Byquist AC, Crown A, Clifton DK, Hoffman GE, Steiner RA, Tena-Sempere M (2007a) Sexual differentiation of Kiss 1 gene expression in the brain of the rat. Endocrinology 148:1774-1783.

Kauffman AS, Park JH, McPhie-Lalmansingh AA, Gottsch ML, Bodo C, Hohmann JG, Pavlova MN, Rohde AD, Clifton DK, Steiner RA, Rissman EF (2007b) The kisspeptin receptor GPR54 is required for sexual differentiation of the brain and behavior. J Neurosci 27:8826-8835.

Kauffman AS, Clifton DK, Steiner RA (2007c) Emerging ideas about kisspeptin-GPR54 signaling in the neuroendocrine regulation of reproduction. Trends Neurosci 30:504-511.

Kinoshita M, Tsukamura H, Adachi S, Matsui H, Uenoyama Y, Iwata K, Yamada S, Inoue K, Ohtaki T, Matsumoto H, Maeda K (2005) Involvement of central metastin in the regulation of preovulatory luteinizing hormone surge and estrous cyclicity in female rats. Endocrinology 146:4431-4436.

Lapatto R, Pallais JC, Zhang D, Chan YM, Mahan A, Cerrato F, Le WW, Hoffman GE, Seminara SB (2007) Kiss1-/- mice exhibit more variable hypogonadism than Gpr54-/- mice. Endocrinology 148:4927-4936.

Levine JE (1997) New concepts of the neuroendocrine regulation of gonadotropin surges in rats. Biol Reprod 56:293-302.

Li C, Chen P, Smith MS (1999) Identification of neuronal input to the arcuate nucleus (ARH) activated during lactation: implications in the activation of neuropeptide Y neurons. Brain Res 824:267-276.

Liu X, Lee K, Herbison AE (2008) Kisspeptin excites gonadotropinreleasing hormone $(\mathrm{GnRH})$ neurons through a phospholipase $\mathrm{C} /$ calcium-dependent pathway regulating multiple ion channels. Endocrinology 149:4605-4614.
Messager S, Chatzidaki EE, Ma D, Hendrick AG, Zahn D, Dixon J, Thresher RR, Malinge I, Lomet D, Carlton MB, Colledge WH, Caraty A, Aparicio SA (2005) Kisspeptin directly stimulates gonadotropin-releasing hormone release via G protein-coupled receptor 54. Proc Natl Acad Sci U S A 102:1761-1766.

Micevych P, Soma KK, Sinchak K (2008) Neuroprogesterone: key to estrogen positive feedback? Brain Res Rev 57:470-480.

Navarro VM, Fernández-Fernández R, Castellano JM, Roa J, Mayen A, Barreiro ML, Gaytan F, Aguilar E, Pinilla L, Dieguez C, Tena-Sempere M (2004) Advanced vaginal opening and precocious activation of the reproductive axis by KiSS-1 peptide, the endogenous ligand of GPR54. J Physiol 561:379-386.

Petersen SL, Ottem EN, Carpenter CD (2003) Direct and indirect regulation of gonadotropin-releasing hormone neurons by estradiol. Biol Reprod 69:1771-1778.

Revel FG, Saboureau M, Masson-Pévet M, Pévet P, Mikkelsen JD, Simonneaux V (2006) Kisspeptin mediates the photoperiodic control of reproduction in hamsters. Curr Biol 16:1730-1735.

Roshon MJ, Ruley HE (2005) Hypomorphic mutation in hnRNP U results in post-implantation lethality. Transgenic Res 14:179-192.

Seminara SB, Messager S, Chatzidaki EE, Thresher RR, Acierno JS Jr, Shagoury JK, Bo-Abbas Y, Kuohung W, Schwinof KM, Hendrick AG, Zahn D, Dixon J, Kaiser UB, Slaugenhaupt SA, Gusella JF, O'Rahilly S, Carlton MB, Crowley WF Jr, Aparicio SA, Colledge WH (2003) The GPR54 gene as a regulator of puberty. $\mathrm{N}$ Engl J Med 349:1614-1627.

Shahab M, Mastronardi C, Seminara SB, Crowley WF, Ojeda SR, Plant TM (2005) Increased hypothalamic GPR54 signaling: a potential mechanism for initiation of puberty in primates. Proc Natl Acad Sci U S A 102:2129-2134.

Shughrue PJ, Lane MV, Merchenthaler I (1997) Regulation of progesterone receptor messenger ribonucleic acid in the rat medial preoptic nucleus by estrogenic and antiestrogenic compounds: an in situ hybridization study. Endocrinology 138:5476-5484.

Simerly RB, Carr AM, Zee MC, Lorang D (1996) Ovarian steroid regulation of estrogen and progesterone receptor messenger ribonucleic acid in the anteroventral periventricular nucleus of the rat. J Neuroendocrinol 8:45-56.

Smith JT, Clarke IJ (2007) Kisspeptin expression in the brain: catalyst for the initiation of puberty. Rev Endocr Metab Disord 8:1-9.

Smith JT, Popa SM, Clifton DK, Hoffman GE, Steiner RA (2006) Kiss1 neurons in the forebrain as central processors for generating the preovulatory luteinizing hormone surge. J Neurosci 26:6687-6694.

Smith JT, Clay CM, Caraty A, Clarke IJ (2007) KiSS-1 messenger ribonucleic acid expression in the hypothalamus of the ewe is regulated by sex steroids and season. Endocrinology 148:1150-1157.

Wintermantel TM, Campbell RE, Porteous R, Bock D, Gröne HJ, Todman MG, Korach KS, Greiner E, Pérez CA, Schütz G, Herbison AE (2006) Definition of estrogen receptor pathway critical for estrogen positive feedback to gonadotropin-releasing hormone neurons and fertility. Neuron 52:271-280.

Zhang C, Roepke TA, Kelly MJ, Rønnekleiv OK (2008) Kisspeptin depolarizes gonadotropin-releasing hormone neurons through activation of TRPC-like cationic channels. J Neurosci 28:4423-4434. 